\title{
Survey for the Presence of Tobacco Mosaic, Cym- bidium Mosaic, and other Viruses in Orchids
}

\author{
J. Enrique Pérez and Amelia Cortés-Monllor ${ }^{1}$
}

\section{INTRODUCTION}

Orchids are grown commercially in Puerto Rico. There is evidence that the plants are frequently attacked by virus diseases which render them worthless commercially. The economic losses caused by such virus diseases may be expected to increase if radical measures are not taken to prevent their spread.

In 1956, Pérez, et al. $(1)^{2}$, were able to detect the presence of tobaccomosaic virus in a purified preparation of Cattleya leaves from plants showing the "flower-breaking" disease (fig. 1). The virus was detected serologically by means of the precipitin method and also by plant-inoculation tests. Similar results were obtained from a few tests with single orchid plants.

In view of this unexpected finding it was thought best to carry out a serological survey among different orchid nurseries in the Island of Puerto Rico seeking to determine the occurrence of tobacco-mosaic virus in other orchids besides Catlleya and Cattleya hybrids, and to detect possible infection by five other common viruses: Potato virus " $X$ "; tobacco severe etch; tobacco-ringspot virus; pepper mosaic (Potato virus Y); and Cymbidium mosaic, since this last virus is known to be widespread among orchids and is apparently confined to the Orchidaceae $(2,3)$. It was desired also to establish, as far as possible, a correlation between positive serological and plant-inoculation tests with orchid extracts and the presence of symptoms in the leaves and/or flowers of plants from which the extracts were derived.

A total of 13 orchid nurseries was surveyed in Puerto Rico.

\section{MATERIALS AND METHODS}

\section{SAMPLES}

Orchid plants to be tested were selected in the nursery by the orchid growers themselves, samples were collected, and the material was brought to the laboratory.

Leaf-tip samples were obtained by cutting approximately a 2-inch-square portion from apparently diseased, suspected, or normal-appearing leaves. Cuttings were made with scissors previously sterilized by dipping in 95-

1 Bacteriologist, and Research Assistant in Bacteriology, respectively, Agricultural Experiment Station, University of Puerto Rico, Río Piedras, P. R. Thanks are due to Dr.D.D. Jensen for supplying Cymbidium leaves infected with Cymbidium mosaic virus.

2 Italic numbers in parentheses refer to Literature Cited, p. 149. 
percent alcohol and flaming three times. This prevented spread of infection within the nursery.

Four different kinds of samples were collected: 1, Leaves showing one or more of a variety of symptoms such as chlorosis, mottling, necrotic sunken areas, and rings; 2, normal-appearing leaves of plants which had borne flowers with the color-breaking symptom; 3 , normal-appearing leaves of plants with no history or evidence of disease; 4 , flowers showing the colorbreaking symptom and/or other abnormalities; and 5, apparently normal white flowers from plants showing leaf symptoms.

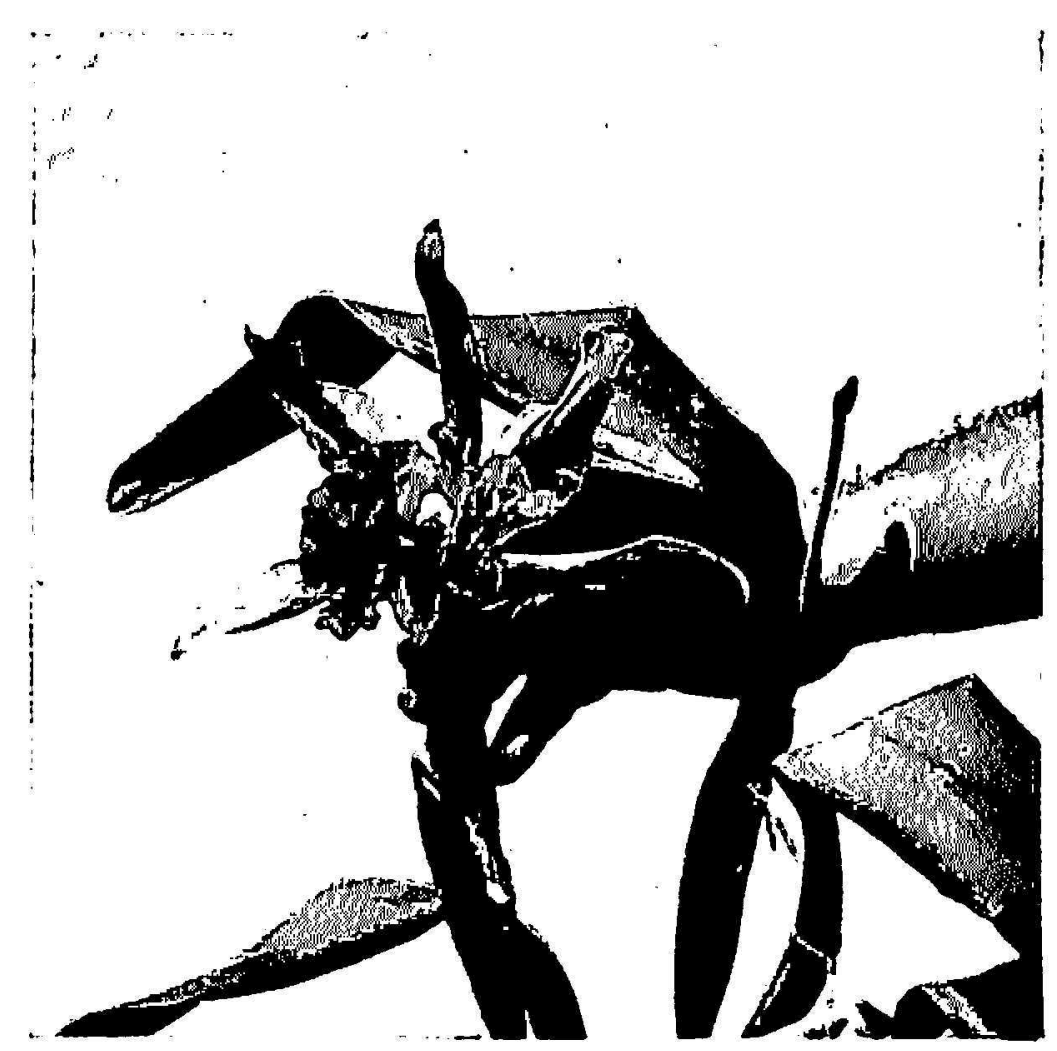

Fra. 1.-Flower from a Catlleya hybrid showing gross color-breaking and distortion. Flowers such as these were shown to be infected by tobacco-mosaic and Cmybidium-mosaic viruses. (Photographed by H. R. Cibes.)

Most samples came from old leaves and older plants. A few, however, were from young leaves. Before serological testing all samples were processed by chloroform treatment as described elsewhere (1), but in extracting young tissue it was found that the addition of dithiocarbamate and the filtration procedure could be omitted. Both chloroform-treated and untreated clarified saps were used for the serological testing of some samples.

\section{SEROLOGICAL TESTS}

The precipitin method was used for the tests. About 0.2 to $0.3 \mathrm{ml}$. of a 120 dilution of each of the following antisera was placed in a $5 \times 60-\mathrm{mm}$. clean test tube: OVP (orchid virus preparation) antiserum (1) and specific 
antisera to the following viruses: Tobacco mosaic, tobacco severe etch, tobaceo-ringspot virus, potato virus $\mathrm{X}$, and pepper mosaic (a strain of potato virus $Y$ ) $(\overline{5})$. For the sake of clearness the viruses and their antisera will be referred to as follows: Tobacco-mosaic virus (TMV); tobacco severe-etch virus (TSE); potato virus $\mathrm{X}\left(\mathrm{J}_{1} \mathrm{X}\right)$; pepper-mosaic virus (PV); and tobacco-ringspot virus (RS). The technique for the preparation of OVP and TMV antisera has been described earlier (1). Antisera for the other viruses were similarly prepared by using partly purified preparations for the inoculation of rabbits.

To each tube was then added 0.2 to $0.3 \mathrm{ml}$. of the orchid-leaf or flowerchloroform extract to be tested. The extract and serum were mixed thoroughly by agitating the contents of each tube with a separate wooden applicator and all tubes placed in a $37^{\circ} \mathrm{C}$. incubator for a maximum of 3 hours. The mixtures were observed for precipitate formation at 15, 30, 60, 120, and 180 minutes after incubation. They were then placed overnight in a refrigerator and observed again after 15 minutes additional incubation at $37^{\circ} \mathrm{C}$. to remove water of condensation from the outer surface of the tubes. Controls were carried out by mixing the extracts in the test with normal rabbit serum and at least one known serologically negative extract with normal rabbit serum and each of the six antisera.

\section{INTERPRETATION OF SEROLOGICAL TESTS}

The formation of a precipitate after incubation for any of the time intervals recorded above was considered evidence of the presence of virus, provided the controls remained negative. Very few instances of nonspecific precipitation occurred with the chloroform extracts even after overnight incubation in the refrigerator.

\section{CROSS-ABSORPTION TEST}

The OVP antiserum was mixed separately both with clarified sap and chloroform extract from a Cymbidium leaf infected with Cymbidium-mosaic virus (CMV). There was a strong precipitin reaction, indicating the presence of antibodies to CMV in the OVP serum. The antiserum was then absorbed with the CMV until it no longer gave a precipitin reaction with this virus. However, a positive reaction was obtained when this absorbed serum was tested with purified TMV. Conversely, when the OVP antiserum was absorbed with TMV it still gave a reaction with CMV. This proved that the OVP antiserum contained antibodies for both CMV and TMV. Thus, in the survey, when an extract gave a positive reaction with OVP antiserum, this could be interpreted as indicating that it contained either a strain of CMV or T.MV or a complex of both strains. Therefore, a reaction which was positive with OVP but negative with TMV antiserum was taken to indicate that the extract contained C.IV. 
OVP serum was used unabsorbed in the survey and, therefore, a positive reaction with it is recorded as "OVP". When inoculation of extracts giving this reaction gave the symptoms on Datura stramonium L. described by Jensen and Gold (4) for CMV, the results were recorded as "CMV".

\section{PLANT INOCULATION TESTS}

Twenty orchid-leaf or flower-chloroform extracts which had reacted positive with the OVP or both the OVP and TMV antisera were frozen at $-10^{\circ} \mathrm{C}$. until a number of young vigorously growing nonorchidaceous species were available for inoculation as test plants. A few serologically positive clarified leaf saps were similarly kept. From three to five test plants were usually inoculated with the serologically positive extracts. Five negative extracts were also carried as controls.

After thawing, a sterile cotton swab was dipped into the extract and the wet swab rubbed onto leaves previously dusted with carborundum powder. Each extract was then separately inoculated on a number of plants.

The species used were: Nicotiana tabacum L. (Holmes' NN having the localization factor for tobacco mosaic virus) (6), N. glutinosa L., Gomphrena globosa L., $N$. tabacum L. var. Virginia-12, Lycopersicon esculentum L. var. Marglobe, and Capsicum frutescens $\mathrm{L}$. var. Large Bell Hot. In some tests the following species were also inoculated: Datura metel L., Chenopodium album L., $N$. sylvestris Speg. and Comes, and Phytolacca americana L. These plants were used to detect the presence of any of the viruses tested for serologically. Datura stramonium L. was also included since, as reported by Jensen and Gold (4) and White (9), this species reacts to infection with Cymbidium mosaic with slow-developing local necrotic lesions which appear about 2 weeks after inoculation and are first seen on the most mature leaves. This was our criterion for detecting Cymbidium mosaic in facing the impossibility of using Cymbidiums which do not adapt well to hot tropical climates. Uninoculated plants of all species used were kept as healthy controls.

Serological tests were performed on the inoculated plants in order to confirm the observed results.

\section{RESULTS}

Orchids from a total of 13 nurseries were included in this study. In all, 267 samples were taken. Of these, 250 were leaf-tip samples only, 12 were samples of flower and a leaf-tip from the same plant, and 5 were flower samples only. Samples were distributed as follows: 205 from Cattleya and Cattleya hybrids (Cattleya spp., Brassocattleya, Laeliocattleya, Brassolaeliocattleya); 11 Vandas; 9 Epidendrums; 8 Oncidiums; 4 from Brassavola nodosa; 3 Dendrobiums; 2 Cymbidiums; 2 Phalaneopsis; 2 Arandas; 2 Arachnis, and one each from the following: Renanthera, Gongora, Schombolaelia, 
Spathoglottis, Aerides, Calanthe, and Maxillaria. CMV and TMV were detected together in the Cattleyas, Epidendrum, and Calanthe; and CMV alone in the Cattleyas, Cymbidium, Vanda, Oncidium, Phalaneopsis, Arachnis, Aerides, and Schombolaelia.

In some cases, whole plants were brought to the laboratory by growers who had noticed abnormalities on the leaves and also such symptoms as flower-breaking and reduction in size or deformation of flowers. On the leaves, the majority of plants showed one or more of the following features: Chlorosis, necrotic rings or sunken spots, discoloration, and deformation. However, there were many leaves with doubtful symptoms. It should be emphasized again that a very large majority of samples were taken from old leaves of long-standing plants. There were very few cases of true leaf mosaic. One plant of $\boldsymbol{E}$ pidendrum ciliare, a native species, showed symptoms of very distinct systemic mosaic and it gave a very strong precipitin test with both OVP and TMV antisera.

A large number of serologically positive extracts was obtained from leaves showing the necrotic sunken spots and the irregular elongated streaks described by Jensen and Gold for Cymbidium mosaic virus in Cattleya (4). Although most of the extracts showing a positive reaction with OVP antiserum came from leaves showing these symptoms, a reaction with TMV antiserum was observed with some of them. Thus, this was the symptom pattern better correlated with positive serological reactions. In addition, serologically positive extracts came from leaves showing other symptoms such as leaf deformation and hardening, purplish spots or areas, and chlorotic spots, rings or streaks.

Results of precipitin tests with leaf samples are given in table 1. It may be seen that of a total 207 diseased or suspected leaves, 55 (26.5 percent) reacted with the OVP antiserum only, while 26(12.5 percent) gave a positive reaction with both OVP and TMV antisera. Thus, a total of 39 percent were serologically positive. When a number of the extracts that reacted with OVP serum only were inoculated on Datura stramonium most of them indicated the presence of Cymbidium mosaic virus (CMV) $(4,9)$ (see plant inoculations, table 2).

On the other hand, 126 samples (61 percent) were suspected of disease yet were serologically negative. Most of these plants did not show necrosis but, instead, a variety of indefinite symptoms such as faint light- and darkgreen banding, "diffuse mosaic", dryness, yellowing, lengthwise folds, and some discoloration.

Likewise none of the normal-appearing leaf samples from plants with abnormal flowers gave a positive serological test.

In table 2 it may be noted that, among the 17 flower samples 8 showed the gross color-breaking symptom and, of these, 6 reacted both with the OVP and TMV antisera, 1 reacted with OVP only and 1 was negative. 
Eight other flowers presented symptoms which differed from gross colorbreak: 3 exhibited discolored patches or some abnormality of pigmentation in the labium, 1 had thin white streaks on 3 petals, and 1 showed atrophy of flower segments. Of these 8 flowers, 6 reacted with OVP serum and 2 were negative. On the basis of this limited number of tests it seems that gross color-breaking is more consistently associated with a reaction with both TMV and OVP. On the other hand, a pattern of incomplete or mild

TABLE 1.-Detection of virus in orchids by precipitin tests of extracts from leaf-tip samples ${ }^{1}$

\begin{tabular}{|c|c|c|c|c|c|c|c|c|}
\hline \multirow{2}{*}{ Condition of leaves } & \multirow{2}{*}{$\begin{array}{l}\text { Num- } \\
\text { ber of } \\
\text { sam- } \\
\text { ples }\end{array}$} & \multicolumn{6}{|c|}{ Reaction with antisera? } & \multirow{2}{*}{ Total negative } \\
\hline & & $\begin{array}{l}4 \\
1 \\
5 \\
5\end{array}$ & $\overrightarrow{\mathrm{g}}_{0}$ & : & & & â & \\
\hline 1. Abnormal leaves: & & & & & & & & \\
\hline $\begin{array}{l}\text { (Symptoms present } \\
\text { or suspected-flower } \\
\text { unknown) }\end{array}$ & 207 & $\begin{array}{l}26(12.5 \\
\text { percent })\end{array}$ & $\begin{array}{l}55(26.5 \\
\text { percent })\end{array}$ & & & & - & $\begin{array}{l}120(01 \text { per- } \\
\text { cent) }\end{array}$ \\
\hline $\begin{array}{l}\text { 2. Normal leaves: } \\
\text { a. Abnormal flower } \\
\text { reported }\end{array}$ & 6 & - & - & - & - & - & $-1-$ & 6 \\
\hline $\begin{array}{l}\text { b. Normal flower re- } \\
\text { ported }\end{array}$ & 37 & - & - & - & - & - & - & 37 \\
\hline Totals & 250 & 26 & 55 & - & - & & - & 169 \\
\hline
\end{tabular}

${ }^{1}$ Flowers not available for test; condition of flowers reported by growers. The minus sign indicates negative reaction.

${ }^{2}$ Letters designate antisera to the following viruses: OVP (orchid-virus preparation); TMV (tobacco-mosaic virus); $J_{1} X$ (potato virus $\left.X\right) ; P V$ (pepper-mosaic virus); TSE (tobacco severe-etch virus); RS (tobacco ringspot virus).

${ }^{3}$ Positive both with OVP and TMV antisera.

${ }^{4}$ Positive with OVP antiserum only.

break is more consistent with a positive reaction with OVP alone. Only one white-flowered plant was tested (Cattleya Joyce Hannington) (fig. 2). ${ }^{3}$ Both a normal-appearing flower and one leaf from this plant were positive for OVP and TMV. It may be seen that results of precipitin tests with flowers and leaves of the same plant were mostly in good agreement. However, it is evident that virus was more easily detected serologically in flowers.

Table 3 shows the results of the confirmatory tests performed with 25 orchid samples, 20 of which gave a serologically positive reaction while 5

sCallleya hybrid. 
were serologically negative samples. As previously stated (p. 141) a number of plant species including Holmes' hypersensitive $\mathrm{NN}$-tobacco and $\mathrm{Ni}$ cotiana glutinosa were used to confirm the presence of tobacco-mosaic

TABLE 2.-Relationship between serological reaction of extracts from orchid flowers and leaves of the same plant, and observed symptoms

\begin{tabular}{|c|c|c|c|c|}
\hline \multirow{2}{*}{$\begin{array}{l}\text { Plant } \\
\text { No. }\end{array}$} & \multicolumn{2}{|l|}{ Flower } & \multicolumn{2}{|l|}{ Leaf } \\
\hline & Symptoms & $\begin{array}{l}\text { Serological } \\
\text { reaction }\end{array}$ & Symptoms & $\begin{array}{l}\text { Serological } \\
\text { reaction }\end{array}$ \\
\hline 117 & Color-breaking & $\begin{array}{l}\text { OVP' } \\
\text { TMV }\end{array}$ & Chlorotic areas & OVP \\
\hline 130 & do. & Negative & Slightly deformed & Negative \\
\hline 200 & do. & $\begin{array}{l}\text { OVP, } \\
\text { TMV }\end{array}$ & $\begin{array}{l}\text { Necrotic crateri- } \\
\text { form lesions }\end{array}$ & OVP, TMV \\
\hline 229 & do. & $\begin{array}{l}\text { OVP, } \\
\text { TMV }\end{array}$ & $\begin{array}{l}\text { Chlorotic and ne- } \\
\text { crotic lesions }\end{array}$ & OVP, TMV \\
\hline 244 & do. & $\begin{array}{l}\text { OVP, } \\
\text { TMV }\end{array}$ & No symptoms & Negative \\
\hline 255 & do. & OVP & Doubtful & Do. \\
\hline 260 & do. & $\begin{array}{l}\text { OVP, } \\
\text { TMV }\end{array}$ & $\begin{array}{l}\text { Chlorotic and ne- } \\
\text { crotic lesions }\end{array}$ & OVP, TMV \\
\hline 251 & Color-breaking-small flower & $\begin{array}{l}\text { OVP, } \\
\text { TMV }\end{array}$ & (2) & (2) \\
\hline 129 & White flower & $\begin{array}{l}\text { OVP, } \\
\text { TMV }\end{array}$ & $\begin{array}{l}\text { White streaks on } \\
\text { under surface }\end{array}$ & OVP, TMV \\
\hline 29 & $\begin{array}{l}\text { Single, thin white streaks on } \\
3 \text { petals }\end{array}$ & OVP & Chlorotic areas & OVP \\
\hline 201 & $\begin{array}{l}\text { Deformation; atrophy of } \\
\text { flower segments }\end{array}$ & OVP & Unknown & OVP \\
\hline $\begin{array}{l}203 \\
204\end{array}$ & $\begin{array}{c}\text { Greenish spots (insect bites) } \\
\text { do. }\end{array}$ & $\begin{array}{l}\text { Negative } \\
\text { OVP }\end{array}$ & $\begin{array}{c}\text { No symptoms } \\
\text { do. }\end{array}$ & $\begin{array}{l}\text { Negative } \\
\text { Do. }\end{array}$ \\
\hline 240 & $\begin{array}{l}\text { Pigment increase on one side } \\
\text { of labium, small flower }\end{array}$ & Negative & (2) & (2) \\
\hline 231 & $\begin{array}{l}\text { Irregular, discolored patch } \\
\text { on labium }\end{array}$ & OVP & (2) & (2) \\
\hline 250 & $\begin{array}{l}\text { Mild color-break (underside } \\
\text { of labium) }\end{array}$ & OVP & (2) & (2) \\
\hline 252 & $\begin{array}{l}\text { Pigment increase on one side } \\
\text { of petal }\end{array}$ & OVP & (2) & (2) \\
\hline
\end{tabular}

1 Positive reaction with OVP (orchid-virus preparation antiserum); positive reaction with TMV (tobacco-mosaic virus antiserum).

2 No sample.

virus. Datura stramonium was the sole indicator used to detect CMV (4). Samples 13 to 23 and 103 were not tested for CMV by plant inoculation. In table 3 it may be seen that from the majority of samples which reacted 
with OVP and TMV antisera and were tested on plants, both CMV and TMV were recovered (samples $28,40,53,55$, and 245 ). On the other hand, TMV was recovered from 3 samples (Nos. 17, 20, and 32) which had reacted serologically with OVP but not with TMV antiserum. In all samples serologically positive for TMV, this virus was detected by both plant inoculation and serological tests of the inoculated plants or by plant inoculation alone. Finally sample 130A, a "broken" flower which was serologically negative, yielded both TMV and CMV upon plant inoculation, but the very

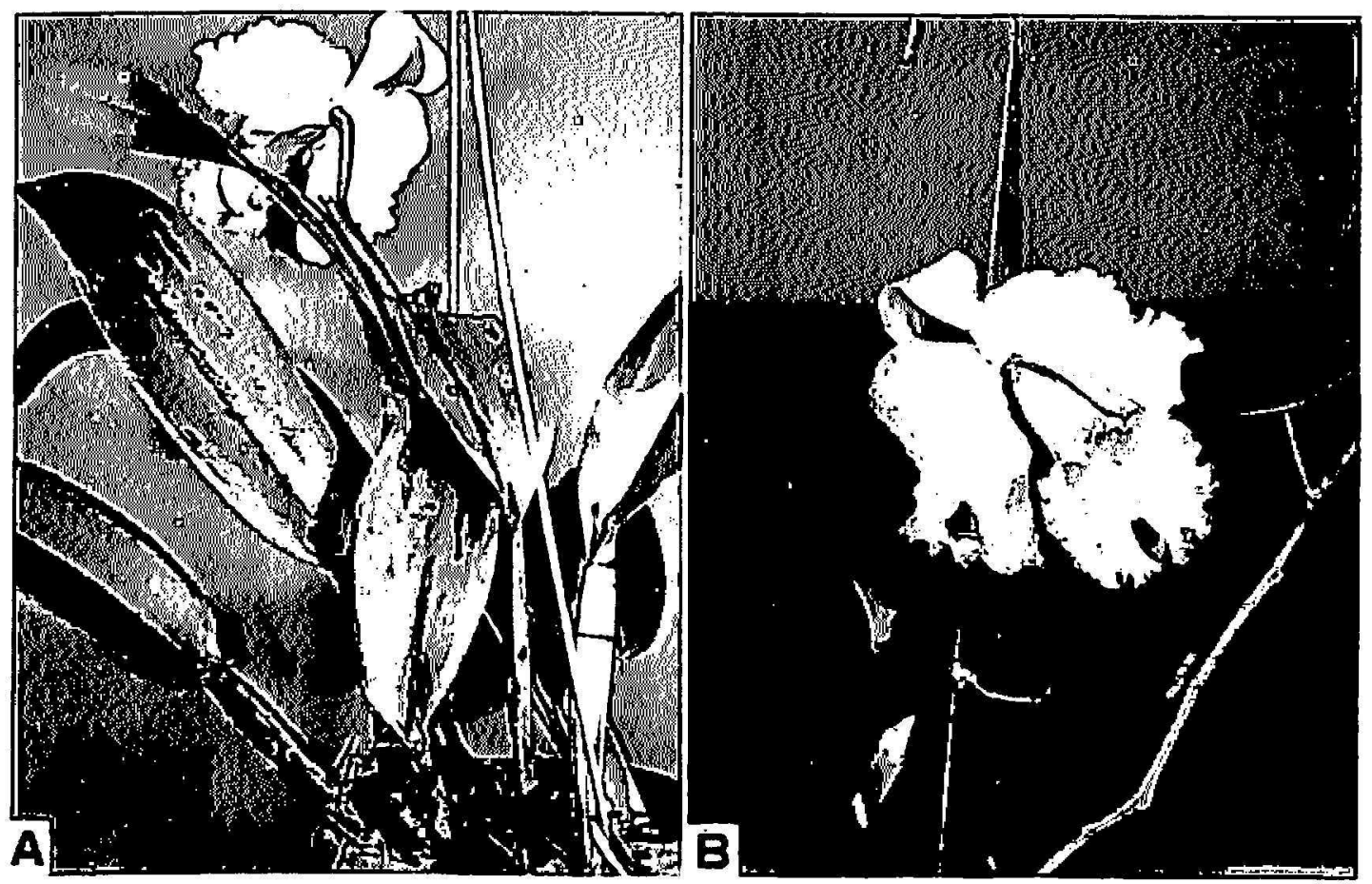

Frg. 2.-A, Catlleya Joyce Hannington; notice necrotic streaks and sunken spots on lenves. An extract from a cut leaf-tip was serologically positive with both TMIV and OVP antisera. B, A normal-appearing white flower of the same plant which, however, was also serologically positive with TMV and OVP antisera.

few local lesions produced on NX-tobaceo, $N$. glutinosa and Datura stramonium, were an indication of the low titer of the viruses present. In like manner the sap from these solanaceous plants gave a weak precipitin reaction with OVP and TMV antisera. This may explain the originally negative serological reaction of the flower. Reactions with the other antisera were all negative.

Results obtained with sample No. 68 (Vanda Cobber Cain) are of particular interest. This sample reacted positive with OVP and negative with TMIV antiserum. Upon inoculation on Datura stramonium it gave the expected delayed local lesions of CMV $(4,9)$. Although no symptoms were obtained on either Virginia 12 tobacco or Chenopodium album, extracts from leaves 
of these two species gave a positive serological test with the OVP serum only. This suggests that multiplication of CMV may take place in these species in the absence of expressed symptoms.

TABLE 3.-Results of confirmation of serological reaction of extracts from orchid-leaf and flower samples through virus recovery and serology of inoculated test plants

\begin{tabular}{|c|c|c|c|c|}
\hline \multirow{2}{*}{$\begin{array}{c}\text { Orchid } \\
\text { sample } \\
\text { So. }\end{array}$} & \multirow{2}{*}{ Source } & \multirow{2}{*}{$\begin{array}{l}\text { Reaction with } \\
\text { antiserum }\end{array}$} & \multicolumn{2}{|c|}{ Confirmatory tests } \\
\hline & & & Symptoms & $\begin{array}{l}\text { Reaction with } \\
\text { antiserum }\end{array}$ \\
\hline 13 & Brassocatlleya Anna Sladden & OVP, TMV & TMVI & TMV \\
\hline 17 & Lacliocallleya Dulzura & OVP & TMV' & TMV \\
\hline 20 & L. Sargon & OVP & TMVı & TMV \\
\hline 21 & $L$. Isabel Sanders $\mathbf{x}(?)$ & OVP, TMV & TMV1 & TMV \\
\hline 22 & $\begin{array}{l}\text { Brassolaeliocattleya Kiensing- } \\
\text { ton }\end{array}$ & OVP, TMV & TMIV' & TMV \\
\hline 23 & B. Nanette & OVP, TMV & TMV 1 & TMV \\
\hline 28 & Calleya Joyce Hannington & OVP, TMV & CMV, TMV & OVP, TMIV \\
\hline $29 \mathrm{~A}$ & $B$, Normans Bay ${ }^{2}$ & $\mathrm{OVP}^{\prime}$ & CMV & OVP \\
\hline $29 B$ & B. Normans Bay & OVP & CMIV & OVP \\
\hline 30 & B. Dorothy Fennel & OVP & CMV & OVP \\
\hline 32 & B. Nigeria & OVP & CMV, TMV & OVP \\
\hline 40 & C. Ardens & OVP, TMIV & CMV, TMV & OVP, TMV \\
\hline 53 & Epidendrum radicans & OVP, TMV & CMV, TMV & OVP, $\mathrm{TMV}^{3}$ \\
\hline 55 & E. radicans & OVP, TMV & CMV, TMV & OVP, TMV 3 \\
\hline 68 & Vanda Cobber Cain & OVP & CMV & OVP \\
\hline 69 & $V$. teres & OVP & CMIV & OVP \\
\hline 103 & E. ciliare & OVP, TMV & TMVı & Not done \\
\hline 124 & $L$. Tokyo rose & OVP & Negative & Negative \\
\hline 132 & B. Normans Bay & OVP & $\mathrm{CMV}$ & OVP \\
\hline 245 & C. Priscilla alba & OVP, TMV & CMV, TMV & Not done \\
\hline 47 & C. giqas & Negative & Negative & Negative \\
\hline 59 & L. Canhamiana alba & do. & do. & Do. \\
\hline 109 & C. labiala & do. & do. & Do. \\
\hline 113 & C. Gaskelliana & do. & do. & Do. \\
\hline $130 \mathrm{~A}$ & L. Cantalo $\times(\text { ? })^{5}$ & do. & CMV, TMV० & $\begin{array}{l}\text { CMV, TMV } \\
\text { (weak) }\end{array}$ \\
\hline
\end{tabular}

1 Not tested for C.MV on Dalura stramonium.

2 Flower sample-thin white streaks on 3 petals of lavender-colored flower.

${ }^{3}$ Reaction tested on Gomphrena globosa leaves only.

- This sample is another from same plant as $29 \mathrm{~A}$, tested more than 1 year later.

s Flower sample-color-breaking.

- Very few lesions obtained.

When a number of serologically positive orchid chloroform extracts was titrated against constant concentrations of OVP and T.MV : nntisera, they gare much higher titers with the OVP $(1 / 16$ to $1 / 32)$ than with TMV anti- 
serum ( $1 / 2$ to $1 / 4$ ), showing that CMV was found in much higher concentration than TMV in the extracts.

\section{DISCUSSION}

The results obtained from this serological survey further confirm the previous report on the presence of tobacco-mosaic virus (TMV) in Cattleya orchids and also show its presence in Epidendrum and Calanthe. It is interesting to observe that TMV was always found in association with Cymbidium mosaic virus (CMV). However, CMV was encountered alone in a larger number of orchid genera. This is in agreement with the findings by previous workers $(2,3,4)$ of its predominating occurrence.

The fact that orchid flowers showing the color-breaking or variegation symptom were shown to contain both CMV and TMV, is of interest in connection with the sinuous-particle:rigid-particle complex found by Murakishi (8) and Newton and Rosberg (10), in association with colorbreak. Murakishi stated that the virus complex found in plants showing the color-break symptom is made up of a mixture of CMV (flexuous particles) and Odontoglossum ringspot virus (ORS-rigid particles). The findings here reported strongly suggest that the color-break virus complex may be made up of CMV and TMV. Plant inoculation and serological tests with ORS indicate its relationship to TMV (11). However, because of discrepancy in the reported size and morphology of ORS and TMV particles (12), a further re-examination of this problem is necessary.

Perhaps another interesting result from this survey is the finding that orchid flowers showing mild pigment disturbances were serologically positive only with OVP serum. This could signify: 1 , That CMV alone is able to cause some form of pigment disturbance, or 2 , that in this condition TMV is present in serologically undetectable amounts. This second explanation is the more plausible since some samples that reacted originally only with OVP serum were later shown to contain TMV by inoculation of nonorchidaceous hosts and serological testing of these hosts.

Further on, if flower color-break is caused by a complex of CMV and TMV, as our findings suggest, then the problem of insect transmission of color-break should be re-investigated. It has been shown by Jensen ( 8 ) that aphids may transmit color-break from flowers showing this symptom to healthy buds. If confirmed, this could mean that a virus complex involving TMV as one of its components is transmitted by aphids. This should prove a very interesting finding.

The results also show that the only viruses isolated from orchids were CMV and TMV, although tests were carried out to detect other viruses both serologically and by plant inoculation. However, the possibility of the existence of viruses which are not transmissible outside the Orchidaceae, 
and are not serologically related to the ones included in this study, must be clearly borne in mind. In addition, the limitations of the precipitin test employed as a serological technique are clearly shown by results with samples which were serologically negative, yet were shown to contain TMV and/or CMV by plant inoculations. The results with sample 130A, already mentioned, are one example. Likewise, the negative precipitin tests obtained with the normal leaf samples from plants which had borne variegated or "broken" flowers, may be another example of the limitations of the precipitin test. These samples may have come from old infections and therefore virus may have been present on the leaves in amounts insufficient for serological detection. In like manner if these infections had been recently acquired through the flower (8) virus might not have yet reached serologically detectable amounts in the leaves. Pérez, et al. (1), found that after concentration and purification of virus from symptomless leaves of Cattleyas with the flower-breaking disease the preparation obtained had a titer of only $1 / 40$ when measured by the precipitin-endpoint method. Similarly Zaitlin et al. (7) found low yields of virus from Cattleya leaves.

\section{SUMMARY}

1. A serological survey carried out in $\mathbf{1 3}$ orchid nurseries in Puerto Rico revealed the presence of tobacco mosaic in association with Cymbidium mosaic in variegated Cattleya flowers and in leaves of Cattleya, Epidendrum, and Calanthe.

2. Cattleya flowers showing mild pigment disturbances were shown to contain CMV only in serologically detectable amounts. Most flowers displaying gross color-breaking were shown to contain in addition, TMV.

3. No definite symptom pattern could be associated with a positive serological reaction, but a large majority of samples displaying the necrotic symptoms of Cymbidium mosaic in Cattleya were serologically positive. The nonreliability of visual observations for virus diagnosis in orchid leaves is further stressed.

4. The limitations of the precipitin test in relation to the present study are discussed.

\section{RESUMEN}

1. Un catastro serológico, llevado a cabo con muestras procedentes de 13 orquidiarios en Puerto Rico, reveló una infección mixta compuesta por el virus del mosaico del tabaco y el virus del mosaico del Cymbidium en flores de Cattleya con jaspeado del pigmento (color-breaking). Se encontró la infección mixta también en hojas de los géneros Cattleya, Epidendrum y Calanthe.

2. En las flores de orquídeas que mostraban un jaspeado benigno (mild 
breaking) se pudo identificar solamente el mosaico del Cymbidium por el método de precipitinas empleado. En las flores con jaspeado pronunciado (gross color-break) se encontró la infección mixta mencionada arriba.

3. No fué posible asociar las reacciones positivas serológicas con sintomas definidos; por otra parte, la mayoría de las muestras tomadas de hojas con sintomas necróticos descritos para el mosaico del Cymbidium en Cattleya, fueron serológicamente positivas. Se destaca la dificultad de diagnosticar síntomas víricos en las hojas de las orquídea por mera observación visual.

4. Se puntualizan las limitaciones de la prueba de precipitina en relación con este estudio.

\section{LITERATURE CITED}

1. Pérez, J. Enrique, Adsuar, J., and Sala, Orlando, Tobacco mosaic virus in orchids in Puerto Rico, Phytopath. 46, 650-4, 1956.

2. Murakishi, Harry H., Host range, symptomatology, physical properties and cross-protection studies of orchid virus isolates, Phytopath. 48, 132-6, 1958.

3. - Serological and morphological relationships among orchid viruses, Phytopath. 48, 137-40, 1958.

4. Jensen, D. D., and Gold, A. H., Hosts, transmission and electron microscopy of Cymbidium mosaic virus with special reference to Cattleya leaf necrosis, $P h y$ topath. 46, 327-34, 1955.

5. Pérez, J. Enrique, and Adsuar, J., Antigenic relationship between Puerto Rican pepper mosaic virus and a strain of potato virus $\mathrm{Y}, J$. Agri. Univ. P. R. 39(3) 165-7, 1955 .

6. Holmes, F. O., Inheritance of resistance to tobacco-mosaic disease in tobacco, Phytopath. 28, 553-61, 1938.

7. Zaitlin, M., Schechtman, A. M., Bald, J. G., and Wildman, S. G., Detection of virus in Cattleya orchids by serological methods, Phytopath. 44, 314-8, 1954.

8. Jensen, D. D., Breaking of Cattleya orchid flowers by orchid mosaic virus and its transmission by aphids, Phytopath. 39, 1056-9, 1949.

9. White, N. H., and Goodchild, J. D., Mosaic or black streak disease of Cymbidium and other orchid hybrids, J. A ustralian Inst. Agr. Sci. 21, 36-8, 1955.

10. Newton, N., and Rosberg, D. W., Electron-microscope studies of a new orchid virus complex, Phytopath. 42, 79-82, 1952.

11. Pérez, J. Enrique, Relationship between Odontoglossum ringspot and tobacco mosaic virus, (in preparation).

12. Jensen, D. D., and Gold, A. H., A virus ringspot of Odontoglossum orehid: Symptoms, transmission, and electron microscopy, Phytopath. 41, 648-53, 1951. 